\title{
Evaluasi Laporan Keuangan dengan Menggunakan CAGR, Analisis Rasio, dan Sistem Du Pont. \\ (Studi Empiris: PT. Adira Dinamika Multi Finance (ADMF) Tbk. Tahun 2010-2019)
}

\author{
Wendra Hartono ${ }^{1}$ \\ ${ }^{1}$ Dosen Universitas Ciputra Surabaya,email; wendra.hartono@ciputra.ac.id
}

\section{ARTICLES INFORMATION}

\section{ABSTRACT}

\section{JURNAL SEKURITAS \\ (Saham, Ekonomi, Keuangan dan Investasi ) \\ Vol.4, No.2, Januari 2021 Halaman : $131-143$ \\ () LPPM \& Prodi Manajemen UNVERSITAS PAMULANG \\ ISSN (online) : 2581-2777 ISSN (print) : 2581-2696}

Keyword :

CAGR; Ratio Analysis; Du Pont System.

JEL. classification :

C33, G21, G24, N15, N25

\section{Contact Author :}

\section{PRODI MANAJEMEN UNPAM}

JL.Surya Kencana No.1

Pamulang Tangerang Selatan Banten

Telp. (021) 7412566, Fax (021) 7412491 Email :

sekuritas@unpam.ac.id
Kondisi perusahaan ADMF yang berfundamental prima, akan sangat menarik bagi para calon investor untuk membeli saham ADMF yang berfluktuatif dan cenderung dalam kondisi up trend. Namun terdapat masalah ekonomi makro yang terjadi selama beberapa tahun terakhir dalam 10 tahun. Penelitian ini akan mengevaluasi laporan keuangan yang meliputi laporan posisi keuangan, laba-rugi dan arus kas perusahaan. Penelitian ini bertujuan untuk memberikan manfaat kepada para calon investor sebagai bahan pertimbangan sebelum membeli saham ADMF. Metode penelitian yang digunakan adalah deskriptif kuantitatif, yang mengukur laporan keuangan dengan menggunakan analisis rasio, CAGR, dan Du Pont sejak tahun 2010-2019. Hasil dari penelitian ini adalah kinerja perusahaan dalam kondisi yang sangat baik, yang dibuktikan dengan nilai analisis rasio, CAGR dan ROI yang selalu positif setiap tahunnya.

The fundamental condition of PT ADMF is in prime, hence it will be interesting to attract investor to buy fluctuated ADMF shares and tends to be in up trend. Nevertheless, there is a macro-economic issue happen during last few years in the last decade. This research will evaluate financial reports which are balance sheet, income statement, and cash flow statement in those company. The aim of this company is giving a benefit for candidate investor as a consideration before making decision to buy ADMF shares. The research method used is quantitative descriptive, which measure financial reports using ratio analysis, CAGR, and Du Pont system since 2010 to 2019. The result of this research is the company performance in a very good condition, proven by the value of ratio analysis, $C A G R$ and $R O I$ are always positive and increase every year. 


\section{A. PENDAHULUAN}

Tujuan dari seorang investor adalah memperoleh imbal hasil yang tinggi di kemudian hari (Marasabessy, 2019). Setiap orang memiliki profil resiko yang berbeda-beda, sehingga dalam pengambilan keputusan serta imbal hasil juga tidaklah sama. Keputusan untuk berinvestasi di pasar modal tentunya memiliki resiko yang tinggi, guna memperoleh imbal hasil yang tinggi pula.

Beberapa investor lebih menyukai berinvestasi di sektor perbank-an ataupun keuangan. Sektor keuangan atau financial sangatlah menarik untuk dicermati dan diperhatikan dalam berinvestasi pasar modal di Indonesia. Sektor ini berperan sangat penting dalam memberikan infomasi dan gambaran tentang kondisi pertumbuhan ekonomi, tingkat inflasi, daya beli konsumen, dan perputaran uang yang terjadi di sebuah negara. Sektor keuangan tersebut meliputi dunia per-bankan dan perusahaan pembiayaan.

Perusahaan yang berkodekan ADMF di pasar bursa ini, didirikan pada tanggal 13 November 1990. Perusahaan ini bergerak di bidang leasing yang bertujuan untuk meminjamkan dana dalam hal sewa guna usaha, usaha pengkreditan, piutang dan pembiayaan konsumen. Salah satu fungsi dari pendanaan ADMF adalah untuk memberikan bantuan pembiayaan bagi masyarakat yang masih membutuhkan dana untuk membeli barang yang berguna mendukung kegiatan hidup sehari-hari, misalnya pembiayaan kendaraan bermotor.

Selama tahun 2010-2019, perusahaan pembiayaan ADMF ini mengalami fluktuasi harga pasar saham dan juga perubahan rasio-rasio keuangan yang terjadi, khususnya rasio profitabilitas dan solvabilitas perusahaan. Hal ini terjadi pada tahun 2014-2016, tahun dimana perusahaan-perusahaan mengalami dampak krisis ekonomi global yang terjadi, yang meneybabkan masa sulit pada industri otomotif dan berdampak pada perusahaan pembiayaan ADMF. Penurunan laba bersih perusahaan ditahun tersebut adalah sebesar $56 \%$ dari tahun sebelumnya, dimana penurunan ini merupakan yang terbsesar selama 5 tahun terakhir.

Kinerja sebuah perusahaan dapat dicerminkan ke dalam laporan keuangannya. Untuk mengukur kinerja perusahaan dapat menggunakan pendekatan analisis fundamental laporan keuangan. Menurut Halim dan Sarwoko (2008:35) Laporan keuangan adalah berbagai data-data yang telah diorganisasikan, disesuaikan dengan prosedur-prosedur akuntansi yang konsisten. Adapun salah satu fungsi laporan keuangan yaitu digunakan untuk sebagai salah satu acuan pertimbangan investor dalam mengukur kinerja perusahaan.

Pergerakan harga saham dapat dianalisa dengan dua hal, yaitu fundamental dan teknikal. Menurut Desmaniarti (2016) fundamental analisis dihitung berdasarkan dari kondisi kesehatan keuangan perusahaan. Permasalahan yang diangkat dalam studi ini adalah analisa laporan keuangan atau yang disebut sebagai analisis fundamental mampu memberikan informasi yang baik bagi para calon investor dan akademia untuk berinvestasi di saham ADMF.

Terdapat bermacam-macam alat ukur yang dapat dipakai untuk menganalisis laporan keuangan yaitu, analisis rasio, MVA, EVA, BSC, CAMEL analysis, dan Sistem Du Pont. Pada penelitian ini, peneliti menggunakan analisis rasio dan sistem Du Pont untuk mengukur kinerja perusahaan ADMF selama 10 tahun terakhir. 
Pada penelitian ini, objek yang akan dibahas sebuah perusahaan leasing yaitu ADMF selama 10 tahun untuk dilihat dan dianalisis dari sisi fundamental perusahaannya. Hal ini bertujuan agar penelitian ini dapat digunakan sebagai rujukan bagi para calon investor dan investor sebelum memutuskan untuk berinvestasi di saham ADMF ini.

\section{B. KAJIAN LITERATUR}

\section{Laporan Keuangan}

Laporan Keuangan, Menurut Baridwan dalam Jurnal yang dibuat oleh Riswan (2014), adalah rangkuman dari sebuah proses pencatatan dari ringkasan transaksi keuangan yang telah terlaksana selama tahun buku tersebut. Kegunaan dari laporan keuangan menurut Weygant, et al (2008:58) yaitu:

1. Memaparkan berbagai informasi penting yang berguna bagi para investor dan kreditor dalam membuat keputusan.

2. Membantu memprediksi perkiraan cash flow di masa depan.

3. Mengidentifikasian tentang kekayaan, liabilitas serta ekuitas suatu perusahaan.

Terdapat beberapa komponen dalam laporan keuangan, diantaranya adalah income statement, laporan perubahan kepemilikan laporan posisi keuangan, dan laporan arus kas perusahaan. Pada penelitian ini akan di tinjau beberapa komponen dari laporan keuangan tersebut, yaitu pendapatan yang terdapat dalam income statement dan arus kas perusahaan.

\section{Pertumbuhan pendapatan}

Pertumbuhan penjualan suatu perusahaan dapat mencerminkan suatu keberhasilan perusahaan dalam memanifestasikan investasi di periode masa lalu, dan dapat dijadikan sebagai salah satu alternatif alat prediksi pertumbuhan pendapatan di periode yang akan datang (Deitiana, 2011:59). Laju pertumbuhan pendapatan suatu perusahaan akan mempengaruhi kemampuan ketahanan laba dalam membiayai kesempatan-kesempatan yang akan terjadi di masa mendatang (Baron et al., 1989). Dalam penelitian ini akan dihitung laju pendapatan selama 10 tahun terakhir perusahaan ADMF.

\section{Analisis arus kas}

Arus kas dapat digunakan oleh investor untuk menilai kondisi kesehatan keuangan perusahaan dari sisi arus keluar masuk kas dalam suatu perusahaan. Hal ini dapat digunakan oleh investor untuk memprediksi nilai arus kas dimasa yang akan datang, adanya suatu ketidakpastian dalam hal keuangan, dan nilai pasar suatu perusahaan (Akbar et al., 2011). Selain itu Dickinson (2011) menjelaskan bahwa pendekatan arus kas layak untuk digunakan untuk menganalisis, memprediksi, mengevaluasi imbal hasil dari perusahaan tersebut.

Akan tetapi, terdapat studi yang mengatakan bahwa analisis arus kas tidak memberikan informasi yang berguna bagi para investor, karena informasi dari arus kas tidak memberikan pengaruh ke nilai perusahaan (Firm Value) (Laswad \& Baskerville, 2007). Sampai saat ini analisis arus kas masih tetap menjadi perdebatan akademisi atau investor, untuk dijadikan sebagai analisis fundamental atau tidak, dalam hal ke efektifan terhadap pergerakan harga saham.

\section{Analisis rasio keuangan}

Rasio keuangan yang diteliti dalam penelitia ini, diantaranya adalah profitabilitas, solvabilitas, dan aktivitas :

- Rasio Profitabilitas 
Menurut Hanafi dalam jurnal yang ditulis oleh Dewi (2019) didefinisikan sebagai sebuat angka yang mendeskripsikan kinerja sebuah perusahaan dalam menghasilkan laba dengan memperhitungkan semua kemampuan dan sumber daya yang ada.

Berikut beberapa rasio profitabilitas, diantaranya adalah :

1. NPM

Merupakan sebuah rasio keuangan yang dipakai untuk membandingkan keuntungan perusahaan yang diperoleh dengan jumlah total penghasilan. Rasio ini bertujuan untuk memberikan analisis tentang stabilitas keuangan suatu perusahaan. Selain itu perhitungan NPM juga menunjukkan seberapa besar perusahaan mampu mengubah laju penjualannya menjadi nilai keuntungan perusahaan tersebut.

2. ROA

Merupakan suatu rasio keuangan yang menggunakan harta atau segala sumber daya dalam menghasilkan keuntungan perusahaan. Nilai ROA dinyatakan dalam besaran persentase. Semakin tinggi nilai ROA maka mengindikasikan semakin baik performa perusahaan dalam menggerakkan harta tersebut dalam mendapatkan laba bersih.

3. ROE

Merupakan suatu rasio finansial yang digunakan untuk menilai kemampuan perusahaan dalam mengelola modal sendiri untuk menghasilkan laba perusahaan. Semakin rendah nilai persentase ROE, maka mengindikasikan bahwa semakin buruk performa perusahaan dalam mengelola modal untuk mendapatkan keuntungan bersih.

- Rasio Solvabilitas

Menurut Kasmir dalam jurnal yang ditulis oleh Oktrima (2017) rasio ini menjelaskan kondisi suatu perusahaan dalam melunasi kewajiban jangka panjang guna meningkatkan likuiditas perusahaan. Salah satu contoh rasio solvabilitas.

- Rasio Aktivitas

Menurut Ernawati (2015) rasio ini menjelaskan suatu aktivitas atau kegiatan yang dilakukan oleh sebuah perusahaan dalam menjalankan kegiatan operasionalnya yang meliputi kegiatan pembelian, penjualan, dan lain-lain. Rasio aktivitas yang dipakai dalam penelitian ini adalah Perputaran Total Aset atau Total Asset Turnover (TOTA).

\section{Analisis Laporan Keuangan dengan sistem Du Pont}

Tujuan dari model Du pont dalam menganalisis laporan keuangan adalah untuk mengukur kinerja keuangan perusahaan. Selain itu, analisis Du Pont bertujuan untuk mengukur efektifitas sebuah perusahaan dalam mengelola modalnya (Maruta, 2018:216). Selain itu menurut Atmaja (2008) menjelaskan bahwa Du Pont sistem dapat menunjukkan bagaimana hutang, pembalikan harta, dan margin laba disatukan untuk menghitung nilai ROE.

Menurut Syamsuddin (2009) Analisis model Du Pont dalam laporan keuangan adalah perhitungan Return on Investment (ROI), yang diperoleh dari perkalian antara jumlah keuntungan yang diterima perusahaan dari penjualan dengan efisiensi total penggunaan aset dalam menghasilkan keuntungan tersebut. Analisis ini mecakup berbagai rasio 
keuangan seperti rasio aktivitas dan profitabilitas terhadap penjualan, yang menunjukkan bagaimana berbagai rasio tersbut saling berpengaruh terhadap tingkat pengembalian atas aktiva (Wasis, 1991).

\section{METODOLOGI PENELITIAN}

Objek dalam penelitian ini adalah perusahaan ADMF yang terdaftar dalam pasar modal Bursa Efek Indonesia (BEI) sejak 31 Maret 2004. Adapun pemilihan waktu yang digunakan dalam penelitian ini adalah dari tahun 2010 - 2019 yaitu selama 10 tahun. Teknik pengumpulan data yang peneliti pakai adalah studi literatur dan penggunaan data sekunder yang diperoleh dari laporan keuangan yang diperoleh dari laman website www.idx.co.id.

Analisis data yang peneliti gunakan adalah dengan metode deskriptif kuantitatif, yang bertujuan untuk mendeskripsikan pertistiwa atau fenomena tentang kinerja laporan keuangan perusahaan yang terjadi selama 10 tahun terakhir. Hal ini didukung dengan kalkulasi yang sesuai dengan keadaan yang diteliti dan dipaparkan dengan mendeskripsikan dalam tabel, grafik, atau bagan.

Berikut ini adalah langkah-langkah yang dipakai dalam metode analisis penelitian ini yaitu :

1. Menghitung laju pertumbuhan pendapatan tahunan rata-rata investasi perusahaan dengan Compound Annual Growth Ratio (CAGR) perusahaan selama 10 tahun terakhir.

2. Menyediakan ringkasan laporan keuangan perusahaan meliputi beberapa komponen dari laporan laba-rugi dan posisi keuangan, dan arus kas perusahaan pada periode 2010-2019.

3. Melakukan perhitungan dengan analisis rasio profitabilitas, solvabilitas, dan aktivitas.

4. Melakukan perhitungan dengan analisis Du Pont pada laporan keuangan periode 2010-2019.

Peneliti akan menggunakan empat buah metode pendekatan, yaitu:

1. Perhitungan Coumpound Annual Growth Ratio (CAGR)

Salah satu pendekatan untuk mengetahui suatu perusahaan berkembang dengan baik adalah dengan mengukur nilai CAGR nya. CAGR (Compound Annual Growth Ratio) merupakan laju pertumbuhan rata-rata investasi tahunan dalam beberapa tahun terakhir yang digunakan lebih dari satu tahun. Dalam perhitungannya, dibutuhkan beberapa komponen seperti jumlah pendapatan dan beban pokok penjualan, untuk menentukan nilai laba kotor dan bersih suatu perusahaan. Setelah mendapatkan nilai laba bersih maka dapat menghitung besar persentase Net Profit Margin (NPM) nya. Net Profit Margin (\%) di ukur untuk menunjukkan nilai perbandingan labar bersih dengan pendapatan.

\section{Perhitungan arus kas.}

Arus kas dibagi menjadi tiga kegiatan utama yaitu, aktivitas operasional, investasi dan pembiayaan ( $\mathrm{Ni}$ et al., 2019). Aktivitas operasional merupakan arus keluar masuknya pendapatan perusahaan yang berhubungan dengan kegiatan utama perusahaan, misalnya produksi, penjualan pembelian dan lain-lain. Sedangkan aktivitas investasi merupakan arus keluar masuknya pendapatan perusahaan yang digunakan untuk kegiatan investasi masa depan perusahaan, misalnya membeli 
saham, aktiva tetap, penjualan surat berharga dan lain-lain. Untuk aktivitas pembiayaan, didefinisikan sebagai arus keluar masuknya pendapatan perusahaan yang dipakai untuk penambahan atau pengurangan modal usaha.

Dalam penelitian ini, perhitungan arus kas, diambil dari laporan keuangan perusahaan setiap tahunnya. Angka positif dan negatif arus kas yang diperoleh di presentasikan dan dibahas dalam bagian bab pembahasan.

3. Perhitungan analisis rasio.

Berikut adalah analisis rasio yang merupakan bagian dari analisis fundamental yang dipakai oleh peneliti yaitu diantaranya:

Tabel 3.1 Formula rasio keuangan

\begin{tabular}{|l|c|}
\hline Rasio & Formula \\
\hline Profitabilitas & Net Prof it Margin $=\frac{\text { Net Income }}{\text { Sales }} \times 100 \%$ \\
\hline & Return on Asset $=\frac{\text { Net Income }}{\text { Total Asset }} \times 100 \%$ \\
\hline Sovabilitas & Return on Equity $=\frac{\text { Net Income }}{\text { Shareholder's Equity }}$ \\
\hline Aktivitas & Debt to Equity Ratio $=\frac{\text { Total debt }}{\text { shareholder's equity }} \times 100 \%$ \\
\hline
\end{tabular}


4. Analisis dengan sistem Du Pont.

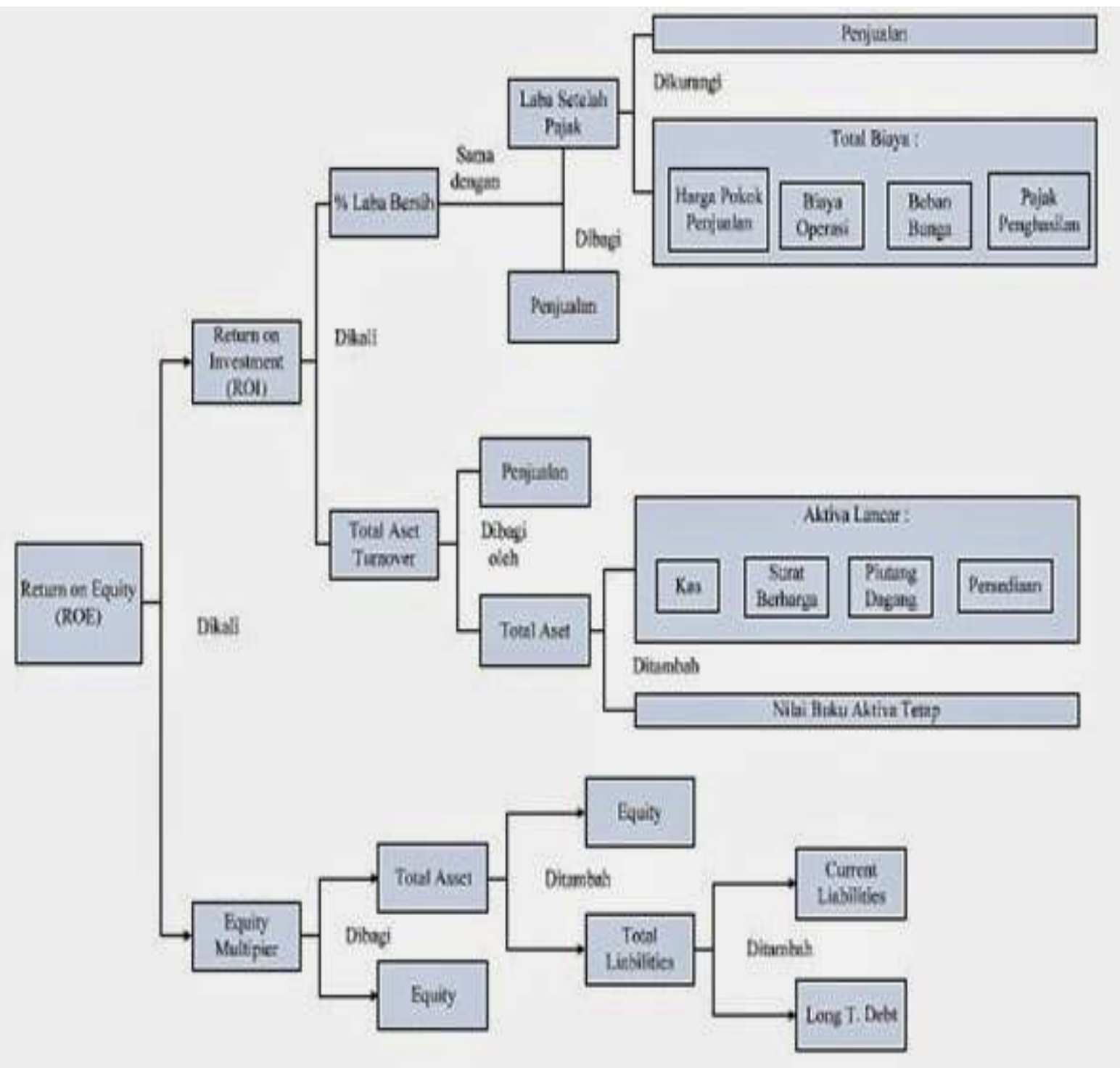

Menurut Reksoprayitno (1991: 137) terdapat beberapa persaman dalam menganalisis Du Pont model yaitu :

a. $\mathrm{ROI}=$ Margin Laba Bersih $\times$ Perputaran Aset Operasi.

b. Margin Laba Bersih = Laba setelah pajak: penjualan bersih.

c. Laba setelah pajak $=$ Penjualan bersih $-($ Harga Pokok Produksi + Biaya Operasional

+ Beban Bunga + Pajak Penghasilan).

d. Perputaran Aset Operasional $=$ Penjualan bersih : Total Aset.

e. Total Aset $=$ Aset tetap + Aset Lancar.

f. Aset Lancar $=$ Kas + Piutang + Persediaan + Surat Berharga .

Dalam hal ini terlihat bahwa perhitungan ROI diperoleh dari persentase laba bersih yang diperoleh dari laporan laba/rugi sedangkan nilai perputaran aset operasi diperoleh dari 
laporan posisi keuangan atau neraca. Hal ini juga menunjukkan bahwa analisis Du Pont ini merupakan suatu analisis laporan keuangan yang terpadu atau terintegrasi.

\section{HASIL DAN PEMBAHASAN}

Pada bab ini akan dibahas empat buah pendekatan yang telah diuraikan pada metode penelitian yaitu :

\begin{tabular}{|c|c|c|c|c|c|c|c|c|c|c|c|}
\hline & 2010 & 2011 & 2012 & 2013 & 2014 & 2015 & 2016 & 2017 & 2018 & 2019 & CAGR \\
\hline Pendapatan & 3,89 & 5,30 & 6,75 & 8,06 & 8,25 & 8,06 & 8,41 & 9,137 & 10,18 & 11,33 & $11,27 \%$ \\
\hline $\begin{array}{l}\text { Beban Pokok } \\
\text { Penjualan }\end{array}$ & $-1,96$ & $-3,19$ & $-4,85$ & $-5,78$ & $-7,19$ & $-7,16$ & $-6,69$ & $-7,02$ & $-7,7$ & $-8,46$ & $15,72 \%$ \\
\hline $\begin{array}{l}\text { Perbandingan } \\
\text { Beban Pokok } \\
\text { Penjualan } \\
\text { dengan } \\
\text { Pendapatan } \\
(\%)\end{array}$ & 50,4 & $60,2 \%$ & 71,9 & 71,7 & 87,2 & 88,8 & 79,6 & 76,8 & 75,6 & 74,6 & \\
\hline $\begin{array}{l}\text { Laba Kotor } \\
\text { Usaha }\end{array}$ & 1,93 & 2,11 & 1,89 & 2,28 & 1,06 & 0,901 & 1,71 & 2,12 & 2,48 & 2,87 & $4,07 \%$ \\
\hline Laba Bersih & 1,46 & 1,58 & 1,42 & 1,71 & 792 & 665 & 1,01 & 1,40 & 1,82 & 2,10 & $3,69 \%$ \\
\hline $\begin{array}{l}\text { Net Profit } \\
\text { Margin (\%) }\end{array}$ & 37,67 & 29,85 & 21,01 & 21,17 & 9,6 & 8,25 & 11,99 & 15,42 & 17,82 & 18,6 & \\
\hline
\end{tabular}

\section{Laju Pertumbuhan Laba dengan analisa CAGR}

Tabel 4.1. Laju Pertumbuhan Laba Perusahaan Adira Finance (dalam miliar rupiah)

Pada Tabel 4.1, menunjukkan bahwa tingkat CAGR pendapatan selama 10 tahun untuk Perusahaan Adira Finance Tbk. adalah sebesar 11,27\%. Angka persentase CAGR ini menunjukkan bahwa laju pertumbuhan pendapatan tahunan meningkat positif sebesar $11,27 \%$ setiap tahun selama 10 tahun. Dari tabel perhitungan diatas maka harus diuji tingkat validitasnya dengan menentukan nilai $R^{2}$ dengan metode grafik dibawah ini.

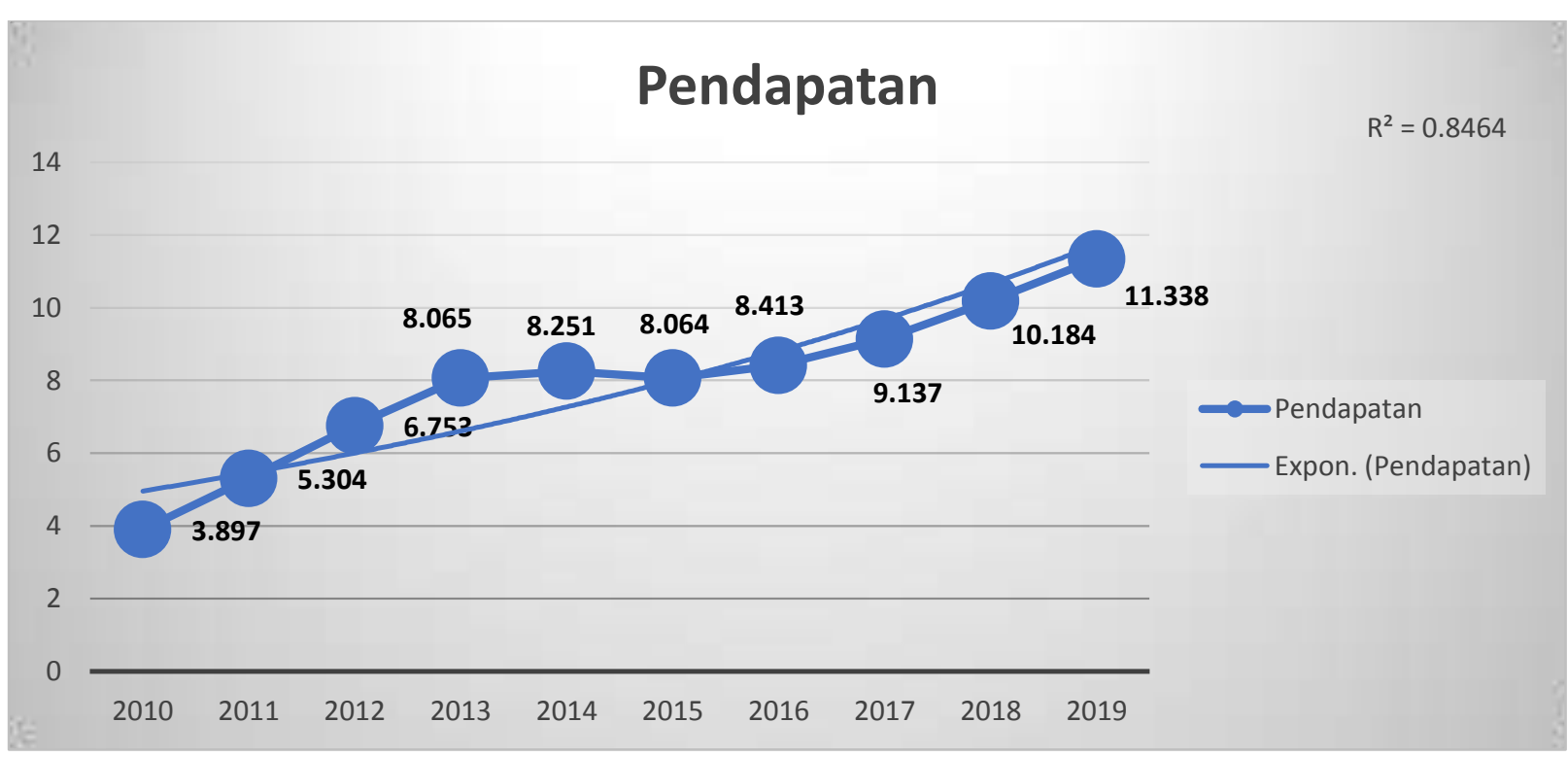




\section{Grafik 4.1 Pertumbuhan Laju Pendapatan ADMF dari Tahun 2010-2019}

Dari Grafik 4.1 menunjukkan nilai laju pendapatan ADMF selama 10 tahun, dengan nilai $R^{2}$ sebesar 0.8464 atau setara dengan $84.64 \%$. Hal ini menunjukkan nilai akurasi CAGR valid sebesar $11,27 \%$.Akan tetapi, beban pokok penjualan juga mengalami laju pertumbuhan tahunan yang cukup signifikan selama 10 tahun yaitu sebesar $15,72 \%$.

Hal ini menyebabkan angka CAGR dari laba kotor dan laba bersih kecil. Pada tahun 2014-2016, terjadi pelonjakan beban pokok pejualan yang cukup tinggi, hal ini dapat dilihat dari nilai persentase beban pokok penjualan terhadap pendapatan, yaitu dari angka $71,7 \%$ di tahun 2013 menjad $87,2 \%$ di tahun 2014, 88,8\% di tahun 2015 dan kemudian turun menjadi $79,6 \%$ di tahun 2016 .

Peningkatan persentase ini disebabkan karena adanya suatu kebijakan pemerintah yang mengubah regulasi pembiayaan tentang rasio uang muka atau down payment terhadap pembelian barang meningkat sebesar $20 \%$ dari angka semula $10 \%$. Hal ini sangat berdampak pada perusahaan Adira Dinamika Multi Finance Tbk ini, yang terlihat dalam penurunan angka persentase Net Profit Margin nya dari tahun 2013 sebesar 21,17\% menjadi 9,6\% ditahun $2014,8,25 \%$ di tahun 2015 dan $11,99 \%$ di tahun 2016 .

\section{Perhitungan Arus Kas}

Tabel 4.2 Arus Kas PT. Adira Dinamika Multi Finance,Tbk. (dalam miliar rupiah)

\begin{tabular}{|l|c|c|c|c|c|c|c|c|c|c|c|}
\cline { 2 - 13 } \multicolumn{1}{c|}{} & $\mathbf{2 0 1 0}$ & $\mathbf{2 0 1 1}$ & $\mathbf{2 0 1 2}$ & $\mathbf{2 0 1 3}$ & $\mathbf{2 0 1 4}$ & $\mathbf{2 0 1 5}$ & $\mathbf{2 0 1 6}$ & $\mathbf{2 0 1 7}$ & $\mathbf{2 0 1 8}$ & $\mathbf{2 0 1 9}$ & Total \\
\hline Operasional & -9.5 & -9.9 & -3.1 & -1.5 & - & & & & & & \\
& & & & & & & & & \\
Investasi & -87 & -136 & -110 & -98 & -142 & -73 & -84 & -92 & -145 & -149 & -1.1 \\
\hline Pembiayaan & 9.7 & 1.2 & 2.7 & 652 & 789 & -2.4 & -2.5 & 366 & 269 & 403 & 22.1 \\
\hline
\end{tabular}

Pada Tabel 4.2 tentang arus kas ADMF diatas menunjukkan arus kas operasional perusahaan keuangan atau pembiayaan menunjukkan angka negatif. Hal ini menunjukkan bahwa laju pertumbuhan kredit perusahaan sangat baik. Hal ini mengindikasikan bahwa perusahaan mampu menyalurkan pinjaman uang kepada nasabah peminjam uang tinggi, sehingga terjadi perputaran arus kas pembiayaan meningkat. Arus kas operasional untuk perusahaan keuangan bernilai positif justru mengindikasikan nilai pertumbuhan kredit yang buruk. Hal ini tampak pada tahun 2015 ke 2017 sebesar Rp 2.657 M, Rp. 2.542 M dan Rp. $1.006 \mathrm{M}$.

Untuk mengukur pertumbuhan arus kas, maka dapat dilakukan dengan menselisihkan nilai kalkulasi penjumlahan nilai arus kas operasional dengan investasi terhadap arus kas pembiayaan. Jika jumlah arus kas pembiayaan bernilai lebih besar dari nilai total arus kas operasional dan investasi, maka arus kas bertumbuh. Hal ini akan mempengaruhi pertumbuhan nilai aset perusahaan. Pada ADMF ini, Jumlah nilai arus kas operasional dan nilai investasi adalah sebesar Rp. 19.506 Miliar, sedangkan nilai pembiayaan arus kas adalah sebesar Rp, 22.142 miliar. Hal ini menunjukkan bahwa perusahaan ADMF mengalami pertumbuhan arus kas selama 10 tahun sebesar Rp. 2.636 Miliar atau sekitar Rp.2,7 T. 


\section{Perhitungan Analisis Rasio}

Tabel 4.3 Nilai Persentase Analisis Rasio ADMF

\begin{tabular}{|c|c|c|c|c|c|c|c|c|c|c|}
\cline { 2 - 13 } \multicolumn{1}{c|}{} & \multicolumn{10}{c|}{ Persentase } \\
\hline & 2010 & 2011 & 2012 & 2013 & 2014 & 2015 & 2016 & 2017 & 2018 & 2019 \\
\hline ROA & 19.32 & 9.37 & 5.57 & 5.51 & 2.65 & 2.4 & 3.65 & 4.78 & 5.76 & 6 \\
\hline ROE & 38.68 & 35.81 & 28.17 & 28.35 & 19.48 & 15.25 & 20.28 & 24.53 & 25.83 & 26.1 \\
\hline DER & 1.00 & 2.82 & 4.06 & 4.15 & 6.36 & 5.36 & 4.55 & 4.13 & 3.48 & 3.35 \\
\hline TATO & 51.32 & 31.38 & 26.51 & 26 & 27.56 & 29.05 & 30.43 & 30.99 & 32.32 & 32.299 \\
\hline
\end{tabular}

Berdasarkan Tabel 4.3 Kinerja keuangan perusahaan dari tahun 2010 sampai 2019, bila ditinjau dari rasio profitabilitasnya, ROA dan ROE mengalami penurunan. Dari tahun 2010 nilai ROA dan ROE menunjukkan nilai yang sangat baik yaitu di angka persentase 19.32 dan 38.68 .

Namun selama 5 tahun kedepan yaitu di tahun 2015, nilai ROA dan ROE mengalami penurunan yang cukup signifikan menjadi 2.4 dan 15.25. Hal ini menunjukkan bahwa efektivitas perusahaan menurun dalam menghasilkan keuntungan. Terjadi pembalikan arah positif untuk nilai ROA dan ROE ke tahun 2019 dari nilai ROA 2.4\% menuju ke 6\% dan $15.25 \%$ menuju ke $26.1 \%$. Hal ini menunjukkan perbaikan daya beli konsumen yang lebih baik dibandingkan tahun 2014. Namun perubahan kenaikan tidak dapat mencapai nilai rasio seperti tahun 2010 yang merupakan angka ROA dan ROE terbaik selama 10 tahun untuk perusahaan ADMF.

Bila ditinjau dari sisi DER (debt to equity ratio) nya dari tahun 2010 sampai 2019, nilai DER meningkat 3.5 kali lipat bila dibandingkan dengan nilai DER di tahun 2010. Nilai DER yang tinggi mengindikasikan bahwa nilai hutang perusahaan yang semakin bertambah dan tingkat resiko pengembalian pinjaman kepada kreditur juga semakin tinggi. Perusahaan pembiayaan memiliki rasio DER yang tinggi dapat juga mengindikasikan kredit macet terjadi oleh kreditur kepada perusahaan ADMF.Dalam upaya meningkatkan likuiditas keuangan, maka perusahaan ADMF menambah rasio hutangnya kepada pihak ketiga.

Dari tahun 2014 sampai 2019, nilai DER berangsur-angsur menurun. Hal ini menunjukkan bahwa perusahaan ADMF memiliki kemampuan mengelola modal yang efektif, sehingga memperkecil hutangnya kepada debiturnya. Selain itu, nilai DER yang rendah dapat juga berarti tingkat kredit macet semakin kecil dan kondisi perekonomian yang semakin membaik dibandingkan dengan tahun 2014.

Dari hasil perhitungan nilai TATO, maka dapat dijelaskan secara keseluruhan nilai TATO menunjukkan angka yang positif. Dari tahun 2010 sampai dengan 2013, terjadi penurunan nilai TATO yang cukup besar dari angka persentase 51.31 sampai dengan 26 . Penurunan ini terjadi karena jumlah total biaya yang dikeluarkan oleh perusahaan ADMF lebih besar dibandingkan dengan jumlah laba bersih yang diterima perusahaan, meskipun nilai penjualannya cukup tinggi. Namun terjadi pembalikan arah persentase nilai TATO sejak tahun 2013 menuju 2018 yang mengalami peningkatan sebanyak 7\%, dan di tahun 2019 masih tetap stabil atau konstan. 


\section{Analisis Sistem Du Pont}

Dalam analisis sistem Du Pont, diperlukan terlebih dahulu perhitungan rasio NPM (Net Profit Margin) dan TATO (Total Asset Turnover).

Tabel 4.4 Nilai Persentase ROI ADMF

\begin{tabular}{|c|c|c|c|c|c|c|c|c|c|c|}
\cline { 2 - 11 } \multicolumn{1}{c|}{} & \multicolumn{10}{c|}{ Persentase } \\
\cline { 2 - 11 } \multicolumn{1}{c|}{} & 2010 & 2011 & 2012 & 2013 & 2014 & 2015 & 2016 & 2017 & 2018 & 2019 \\
\hline ROI & 19.33 & 9.37 & 5.57 & 5.50 & 2.65 & 2.40 & 3.65 & 4.78 & 5.76 & 6.01 \\
\hline
\end{tabular}

Dari Tabel 4.4 menunjukkan nilai persentase ROI PT. Adira Dinamika Multi Finance,Tbk selama 10 tahun cenderung mengalami pertumbuhan, yang di tunjukkan dengan nilai ROI yang positif. Nilai pertumbuhan ROI sempat mengalami penurunan dari tahun 2010 sampai 2014 yang sangat signifikan dari angka persentase 19.33 menjadi 2.65. Nilai penurunan ROI ini mengindikasikan bahwa kemampuan perusahaan ADMF dalam pemanfaatan modal kurang efektif, sehingga modal yang dimiliki perusahaan tidak dapat menghasilkan laba dengan maksimal.

Namun sejak tahun 2015 sampai dengan 2019, nilai ROI menunjukkan kenaikan persentase ROI yang lebih baik. Hal ini dapat mengindikasikan bahwa persuahaan sudah mampu menggunakan seefektif mungkin dalam menghasilkan laba. Selain itu, kenaikan nilai ROI juga dikarenakan adanya pertumbuhan perekonomian nasional mengalami pemulihan dari masalah ekonomi global yang menyebabkan permintaan kredit bertambah.

\section{E. KESIMPULAN}

Dari pemaparan mengenai laju pertumbuhan pendapatan diatas, maka dapat disimpulkan bahwa :

1. Tingkat CAGR pendapatan Perusahaan Adira Dinamika Multi Finance Tbk. (ADMF) meningkat sebesar $11.27 \%$ sejak tahun 2010 sampai dengan 2019.

2. Pergerakan arus kas Perusahaan Adira Dinamika Multi Finance Tbk. (ADMF) menunjukkan kas operasional perusahaan negatif, yang mengindikasikan laju pertumbuhan kredit berkembang baik, kas investasi dan pembiayaan menunjukkan laju pertumbuhan kas yang baik selama 10 tahun.

3. Dari rata-rata hasil analisis rasio yang digunakan yaitu nilai NPM, ROA, ROE, DER, dan TATO mengindikasikan bahwa Perusahaan Adira Dinamika Multi Finance Tbk. (ADMF) menunjukkan kinerja yang prima, meskipun sempat mengalami penurunan persentase tetapi sejak lima tahun terakhir yaitu tahun 2014, kinerja perusahaan sudah membaik.

4. Dari analisis sistem Du Pont Perusahaan Adira Dinamika Multi Finance Tbk. (ADMF) selama 10 tahun, menunjukkan pertumbuhan nilai ROI yang berfluktuatif dengan kecenderungan meningkat setiap tahunnya.

Dari rangkuman butir penting kesimpulan diatas, maka dapat diambil kesimpulan secara keseluruhan bahwa sebuah saham ADMF sangat layak untuk di investasikan dalam kurun waktu jangka panjang. Pengevaluasian kinerja Perusahaan Adira Dinamika Multi Finance Tbk. (ADMF) selama 10 tahun dalam keadaan yang prima, walaupun sempat menghadapi tantangan krisis ekonomi global pada tahun 2014-2016. 
Keterbatasan penelitian ini adalah peneliti hanya menggunakan sedikit rasio keuangan sebagai dasar atau landasan dalam mengintepretasikan data. Hal ini berdampak pada pendeskripsian data keuangan yang belum mencakup secara keseluruhan tentang saham ADMF. Selain itu, pada penelitian ini, peneliti kurang menggunakan laporan keuangan yang lain misalnya neraca keseimbangan yang menunjukkan keadaan harta, hutang dan modal perusahaan dari tahun ke tahun.

Peneliti menyarankan kepada peneliti selanjutnya untuk menggunakan lebih banyak lagi dalam memperhitungkan rasio keuangan yang dipakai. Selain itu, peneliti hanya menyarankan kepada pembaca untuk menggunakan hal ini sebagai salah satu dasar pertimbangan, dan bukan sebagai ajakan atau himbauan untuk membeli saham ADMF.

\section{DAFTAR PUSTAKA}

Abdul Kadim, K., \& Nardi Sunardi, S. (2018). Determinant Of Company's Likuidity And It's Implications On Financial's Performance Of Ritail Trade Company's In Indonesia At The Period Of 2008-2017. Global and Stockhastic Analysis, 5(7), 235-247.

Abdul Kadim, K., \& Nardi, S. (2018). Eviews Analysis: Determinant Of Leverage And Company's Performance. Global and Stochastic Analysis (GSA), 5(7), 249-260.

Akbar, S., et al. (2011). The value relevance of cash flows, current accruals, and non-current accruals in the UK. International Review of Financial Analysis, 20(5), 311-319.

Atmaja, L, S. (2008). Teori dan Praktek Manajemen Keuangan. Yogyakarta: Penerbit ANDI

Barton, S. L., et al.(1989)."An Empirical Test of Stakeholder Theory Predictions of Capital Structure." Journal of the Financial Management Association, Spring.

Deitiana, T. (2011). "Pengaruh Rasio Keuangan, Pertumbuhan Penjualan, Dan Dividen Terhadap Harga Saham." Jurnal Bisnis dan Akuntansi Vol. 13, No. 1, April 2011, Halaman 57-66.

Desmaniarti, T. Effendi, R. Wijaya, T. (2016). Analisis Fundamental dan Analisi teknikal Dalam Menilai Investasi Saham Syariah Yang Tercatat di Bursa Efek Indonesia Periode 2015- 2016, http://eprints.mdp.ac.id/2111/1/Jurnal-2013200078.pdf.

Dewi, S.(2019). "Pengaruh Ukuran Perusahaan dan Profitabilitas Terhadap Pengungkapan Sustainability Report Serta Dampaknya Kepada Nilai Perusahaan." Jurnal Studia Akuntansi dan Bisnis Volume 7, No. 3, Halaman 173-186.

Dickinson, V. (2011). Cash flow patterns as a proxy for firm life cycle. The Accounting Review, 86(6), 1969-1994.

Ernawati, D. (2015). Pengaruh Profitabilitas, Leverage dan Ukuran Perusahaan Terhadap Nilai Perusahaan. Sekolah Tinggi Ilmu Ekonomi Indonesia. Surabaya.

Hakim, L., Sunardi, N. (2017). Determinant of leverage and it's implication on company value of real estate and property sector listing in IDX period of 2011-2015. Man in India, 97(24), pp. 131-148. 
Halim, A dan Sarwoko .(2008). Manajemen Keuangan (Dasar-Dasar Pembelanjaan Perusahaan).Yogyakarta: BPFE, hal. 35.

Husain, T., \& Sunardi, N. (2020). Firm's Value Prediction Based on Profitability Ratios and Dividend Policy. Finance \& Economics Review, 2(2), 13-26.

Kadim, A., Sunardi, N \& Husain, T. (2020). The modeling firm's value based on financial ratios, intellectual capital and dividend policy.Accounting, 6(5), 859-870.

Laswad, F., \& Baskerville, R. F. (2007). An analysis of the value of cash flow statements of New Zealand pension schemes. The British Accounting Review, 39(4), 347-355.

Marasabessy, A., I. et al. (2019). The Effect of Financial Performance on Firm Value and Stock Return (Study on Manufacturing Companies Listed on Indonesia Stock Exchange for the period 2015-2017). International Journal of Social Science an Economic Research Vol 4., ISSN: 2455-8834.

Maruta, H. (2018). "Analisis Laporan Keuangan Model Du Pont Sebagai Analisis Yang Integratif." JAS (Jurnal Akuntansi Syariah) 2 (1), 9-28.

Nardi Sunardi \& T. Husain \& A. Kadim, 2020. "Determinants of Debt Policy and Company's Performance," International Journal of Economics \& Business Administration (IJEBA), International Journal of Economics \& Business Administration (IJEBA), vol. 0(4), pages 204-213.

Oktrima, B.(2017). "Pengaruh Profitabilitas, Likuiditas, dan Struktur Modal Terhadap Nilai Perusahaan (Studi Empiris: PT. Mayora Indah, Tbk. Tahun 2011-2015)." Jurnal Sekuritas Volume I, Nomor 1, September 2017, hal. 98-107.

Reksoprayitno, S. (1991). Analisis Laporan Keuangan: Analisis Rasio. Yogyakarta: Liberty,Edisi 1.

Riswan dan Kesuma, Y. F.(2014). Analisis Laporan Keuangan Sebagai Dasar Dalam Penilaian Kinerja Keuangan PT. Budi Satria Wahana Motor. Jurnal Akuntansi dan Keuangan Volume 5, No. 1, Maret 2014, Halaman 93-121.

Sunardi, N., \& Lesmana, R. (2020). Konsep Icepower (Wiramadu) sebagai Solusi Wirausaha menuju Desa Sejahtra Mandiri (DMS) pada Masa Pandemi Covid-19. JIMF (Jurnal IImiah Manajemen Forkamma), 4(1).

Syamsuddin. (2009). Manajemen Keuangan Perusahaan. Jakarta: PT Raja Grafindo Persada.

Wasis. (1991). Manajemen Keuangan Perusahaan. Semarang: Satya Wacana.

Weygandt, et al. (2007). Accounting Principles, Edisi 7. Penerbit. Salemba Empat. 